\title{
Preliminary survey of the butterflies and skippers (Insecta: Lepidoptera) in a wet subtropical sustainable forestry plot in Patillas, Puerto Rico ${ }^{1}$
}

\author{
George LoCascio III $^{2}$ and Anna Kudryashova ${ }^{2}$
}

\begin{abstract}
The study represents a preliminary survey of butterflies and skippers (Lepidoptera) in a wet subtropical sustainable forestry plot within the boundaries of Las Casas de la Selva located in the municipality of Patillas, Puerto Rico. Eleven species of butterflies and skippers, placed in four families, have been collected establishing a preliminary baseline for further research. Subsequent population monitoring will be conducted in the wet and dry seasons that should allow us to detect general population trends and possible correlations of harvesting forest wood timber. This study and future research may help promote the understanding of biospherics by testing the idea that the harvesting of wet subtropical forest trees in a sustainable manner has a positive effect on the populations and overall species count of Lepidoptera, thus providing a model for a mutually beneficial relationship between native biodiversity and human economic activity.
\end{abstract}

Key Words: Lepidoptera, biospherics, sustainable forestry, Puerto Rico

Las Casas de la Selva is a 1,000-acre plot of wet subtropical forest (Nelson 2010) located in the municipality of Patillas, Puerto Rico that practices sustainable harvesting of trees on some of its land (Figure 1). The property is associated with the Institute of Ecotechnics, which promotes biospherics, a whole systems approach to studying the Earth's ecology (Allen 2009). Analyzing the effects that wet subtropical sustainable forestry has on Lepidoptera (Nelson 2010) is an illustration of a holistic case study approach to species conservation (Pereira Dos Santos 2011). If the research shows that such practices have a positive effect in population and species diversity (Summerville 2011), it will further promote the practices of sustainable forestry (Bergman 2001). Due to their charm and aesthetic appeal, butterflies (insect Order Lepidoptera) can mystify people, especially when seen in nature, and are often chosen as a symbol of conservation efforts (Pereira Dos Santos 2011). Demonstrating that sustainable forestry practices have a positive effect on Lepidoptera can serve as a powerful tool for raising awareness about the importance of species diversity (Lomov et al. 2006), the promotion of wet subtropical sustainable forestry practices, and for the further study of biospherics (Allen 2009) and conservation (Tórrez 2013).

In September 1989, hurricane Hugo passed over the island of Puerto Rico, including the lower elevations in the Luquillo Experimental Forest on the

\footnotetext{
${ }^{1}$ Submitted on August 15, 2012. Accepted on September 10, 2012. Last revisions received on September 29, 2013.

${ }^{2}$ Bunker Hill Community College, Boston, Massachusetts 02129 USA. E-mails: georgelocascio@gmail.com, annacogito@gmail.com, respectively.
}

DOI: 10.9784/LEB1(3)LoCascio.05

Electronically available on October 14, 2013. Mailed on October 12, 2013. 
northeast side of the island. Having led to extensive tree damage of forest species, it opened the canopy for some time to allow a successional change in forest composition (Walker 1991, see also Torres 1992). Such a change in plant species could provide opportunities for the growth of host plants of butterflies (Ehrlich 1964), which thrive in open-canopy forest habitats (Hughes 1998). Thus, our objectives are, but not limited to: a) conducting a baseline butterfly species survey, b) conduct a population count of multiple species, and c) future analysis of data from both to determine the effects of wet subtropical forestry practices on Lepidoptera populations, respective host plants, and the diversity of species.



Figure 1. Map of Las Casas de la Selva's main road where the line and dots represent the waypoints marked every 30 seconds on a Garmin handheld GPS unit. Insert represents the island of Puerto Rico and the square within it, the approximate location of study site.

\section{Study Area}

\section{Methods}

Las Casas de la Selva's main buildings are located in the municipality of Patillas, Puerto Rico (latitude 18-04'757' N, longitude 066-02'114'W). Wet subtropical forests of Puerto Rico are diverse biologically and geographically, occurring primarily as secondary growth in former agricultural or pasture lands or as primary or successional growth within remnant, protected forest reserves with low variability in annual temperature and high levels of rainfall (Hall 2011). The property borders the Carite National Forest on the north and private lands elsewhere. Elevation ranges from 300-600m, average temperature $\sim 22^{\circ} \mathrm{C}$, and annual rainfall is averages over $3,000 \mathrm{~mm}$ (Vakil 2012). Forest composition 
is dominated by semi-evergreen and evergreen deciduous trees where various compositional cover types exist. The dominant tree species are tabonuco, Dacryodes excelsa Vahl (Burseraceae) and granadillo, Buchenavia tetraphylla (Aubl.) R. A. Howard (Combretaceae). According to The Plant List, http://www.theplantlist.org/, B. capitata (Vahl) Eichler is a synonym of $B$. tetraphylla. The understory is composed primarily of several species of camasey (Miconia and Calycogonium, Melastomataceae) and a variety of pteridophytes (ferns and their botanical allies), including Adiantum, Pteridaceae; Arachniodes, Dryopteridaceae; Blechnum, Blechnaceae; Cyathea, Cyatheaceae; Lomariopsis, Lomariopsidaceae; Lycopodium, Lycopodiaceae; Nephrolepis, Davalliaceae; Polybotrya, Dryopteridaceae; Selaginella, Selaginellaceae; Sticherus, Gleicheniaceae; and Thelypteris, Thelypteridaceae) (Vakil 2012).

\section{Butterfly Species Surveys}

The collection dates for the four butterfly species surveys were 6-18 August 2012, 10-12 January 2013, 27-30 May 2013, and 29-31 July 2013. Butterfly species surveys were conducted from 08:00-20:00 in a variety of weather conditions ranging from full sunny to rainy days and nights using entomological hand nets and cylindrical traps baited with banana, mango, and orange fruits (Figure 2). Butterflies were collected along a ca. $1.1 \mathrm{~km}$. transect that takes ca. 1.5 hours to walk. Traps were set off the ground in between the distances of 2.5$6 \mathrm{~m}$. For the butterfly species survey, one trap was set along the main road and the other was set around the main buildings of Las Casas de la Selva. Specimens were mounted following standard entomological protocols and the vouchers plan to de deposited to the entomological collection of Las Casas de le Selva.



Figure 2. Tools for population monitoring and sample species survey. Left, a bait trap; right, an entomological net. 


\section{Butterfly Population Surveys}

The first two population monitoring surveys were conducted on 27 May 2013 and on 30 July 30. Population monitoring surveys were carried out with entomological nets only and were conducted between 10:00-14:00, on sunny to partly cloudy days with wind speeds under $16-\mathrm{km} / \mathrm{h}$.

\section{Results, Discussion, Limitations, and Future Research Species Surveys}

Eleven species of butterflies and skippers placed in four families of Lepidoptera have been collected. This represents approximately $10 \%$ of the butterflies known to Puerto Rico (Pérez-Asso et al. 2009). The species listed in alphabetically by genus are: Calisto nubila (Lathy, 1899) Nymphalidae (Figure 3a), Choranthus vitellius (Fabricius, 1793) Hesperiidae (Figure 3b), Colobura dirce wolcotti (Comstock, 1942), Nymphalidae (Figure 3c), Dismorphia spio (Godard, 1824) Pieridae (Figure 3d), Eurema daira palmira (Godard, 1819) Pieridae (Figure 3e), Heliconius charitonia (Linnaeus, 1767) Nymphalidae (Figure 3f), Heraclides pelaus puertoricensis (Golman and Salvin, 1890) Papilionidae (Figure 3g), Papilio androgeus (Cramer, 1775) Papilionidae (Figure 3h), Pyrisitia portoricensis (Dewitz, 1877) Pieridae (Figure 3i), Pyrgus oileus (Linnaeus, 1767) Hesperiidae (Figure 3j), and Siproeta stelenes (Linnaeus, 1758) Nymphalidae (Figure 3k). Three relatively large species of moth (not included in the percent calculation) were found: Pseudosphinx tetrio (Linnaeus, 1771), Agrius cingulata (Fabricius, 1775; both Sphingidae, Figures 31-o), and Diaphania hylinata (Linnaeus, 1767) Crambidae (Figure 3p). Other species of moths (not figured and yet to be identified), have also been collected.

\section{Population Surveys}

The combined results of the first (May) population monitoring yielded the following five species and 40 individuals (followed by numbers observed): Dismorphia spio (4), Calisto nubila (28), Colobura dirce wolcotti (1), and Choranthus vitellius (7). Also three other butterflies were sighted but could not be identified. The combined results of the second (July) population monitoring yielded the following three species: C. nubila (41), C. vitellius (4), Dryas julia (1). Also, another butterfly was seen but could not be identified. These preliminary results between the two monitoring dates show an increase in sightings of $C$. nubila, and a decrease in sightings of $C$. vitellius but sampling needs to be repeated for several more years. 

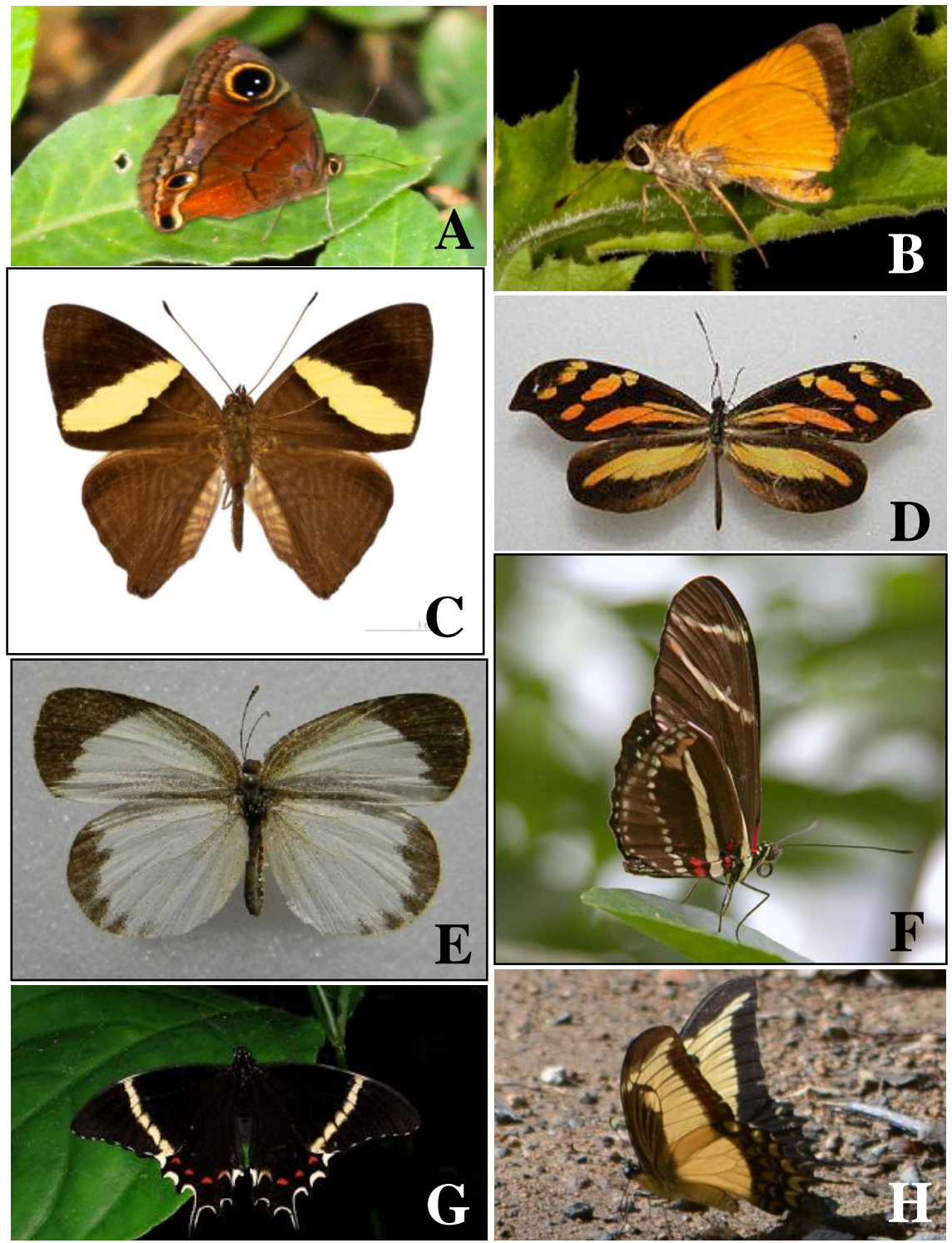

Figures 3A-P. a. Calisto nubila (Lathy, 1899) Nymphalidae, photo credit George LoCascio III; b. Choranthus vitellius (Fabricius, 1793) Hesperiidae, photo credit Alejandro Sánchez, reproduced with permission; c. Colobura dirce wolcotti (Comstock, 1942), Nymphalidae, http:/upload.wikimedia.org/wikipedia/commons//0a/Colobura dirce dirce MHNT.jpg; d. Dismorphia spio (Godard, 1824) Pieridae, photo credit http://upload.wikimedia.org/wikipedia/commons/thumb/5/59/Dismorphia_spio2.jpg/266p x-Dismorphia spio2.jpg; e. Eurema daira palmira (Godard, 1819) Pieridae, photo credit 

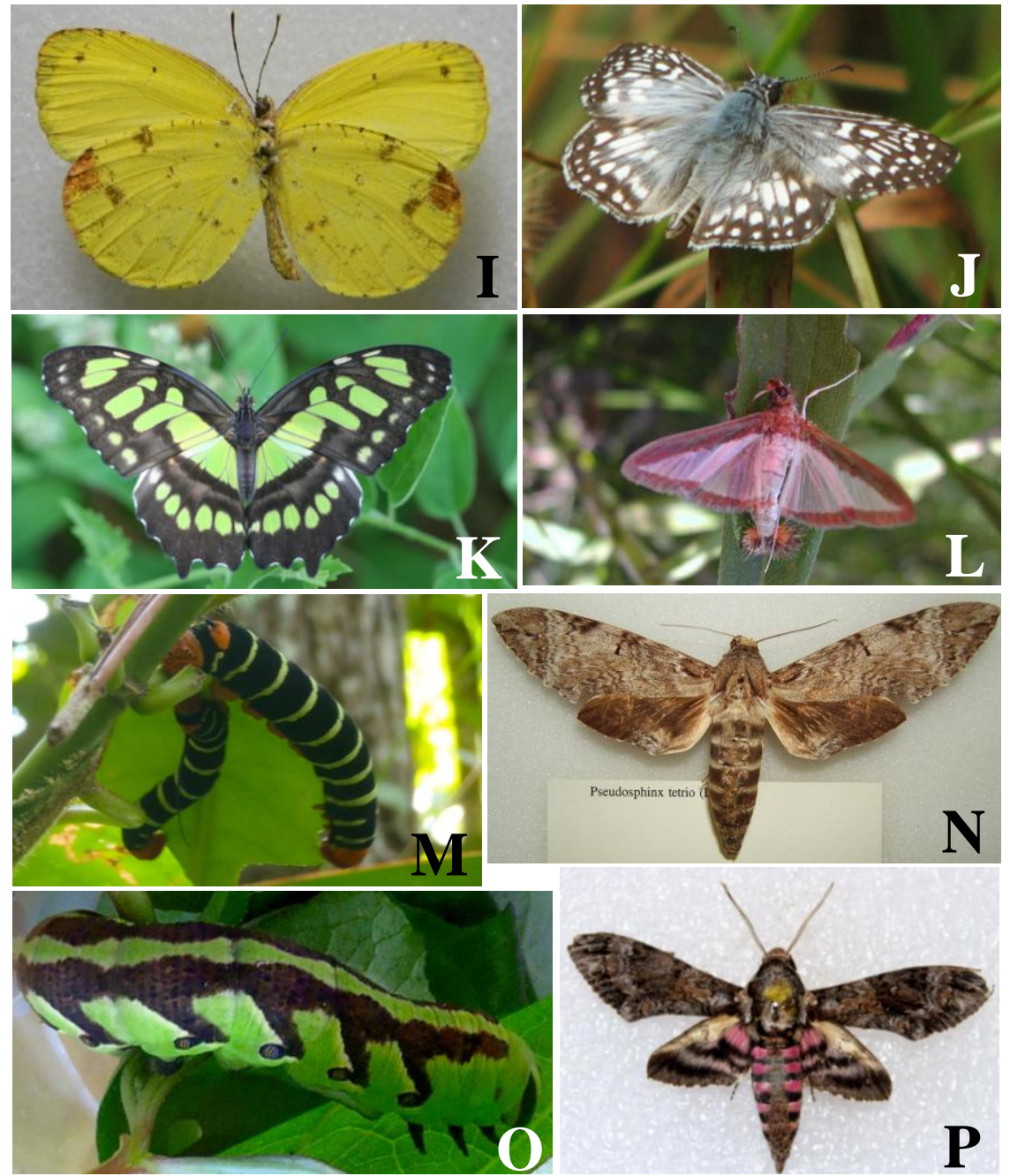

Julio A. Genaro, reproduced with permission; f. Heliconius charitonia (Linnaeus, 1767) Nymphalidae, photo credit Greg Hume, reproduced with permission; g. Heraclides pelaus puertoricensis (Golman and Salvin, 1890) Papilionidae, photo credit Ricardo Valentín, reproduced with permission; h. Papilio androgeus (Cramer, 1775) Papilionidae, photo credit Andrés Rúa, reproduced with permission; i. Pyrisitia portoricensis (Dewitz, 1877) Pieridae, photo credit Julio A. Genaro, reproduced with permission; j. Pyrgus oileus (Linnaeus, 1767) Hesperiidae, photo credit B. A. Bowen, reproduced with permission; $\mathrm{k}$. Siproeta stelenes (Linnaeus, 1758) Nymphalidae, photo credit Anne Toal, reproduced with permission; 1. and m. Pseudosphinx tetrio (Linnaeus, 1771), photo credit Shawn Hanrahan, reproduced with permission; n. and o. Agrius cingulata (Fabricius, 1775 photo credit George LoCascio III (1 to o, Sphingidae); p. Diaphania hylinata (Linnaeus, 1767) Crambidae, photo credit Tom Peterson, reproduced with permission. 


\section{Limitations}

The literature on the use of butterflies as bioindicators is large and the analysis of the data is often complicated (e.g. Bazelet and Samways 2011, Fleishman and Murphy 2002, Miller et al. 2011, Osborn et al. 1999, Pearson and Caroll 1998, Spitzer at al. 1997, Stefanescu et al. 2005). A search on Google Scholar using the phrase butterflies bioindicators yielded over 1,000 hits; the same search on Google yielded over $300 \mathrm{~K}$ hits. In a study of the Speckled Wood nymphalid butterfly, Pararge aegeria(L.), "results suggest that differential selection regimes associated with different landscapes intervene by intraspecific variation in the response of a butterfly to variation in ambient temperature, and may thus be helpful when making predictions of future impacts on how wild populations respond to environmental conditions under a global change scenario, with increasing temperatures and fragmented landscapes." (Karlsson and Van Dyck 2005).

This pilot study suffers from limitations typical of the initial phases of research. First, a number of factors were not taken into consideration while conducting the survey/monitoring: season, life histories of Lepidoptera, potential host plants, etc. Second, some of the group monitors were unfamiliar with entomological netting techniques and may have failed to recognize some species. Both the sample species survey and the population monitoring are preliminary baseline numbers. More research is to be conducted in both the wet and the dry seasons as well as in areas with different vegetation to provide insights into longer-term patterns. We are finalizing the search for a comparable plot where sustainable forestry in not practiced $r$ to compare the corresponding effects of wet subtropical forestry on resident Lepidoptera fauna.

\section{Acknowledgments}

We would like to thank Thrity Vakil and Andres Rúa from Las Casas de la Selva (Patillas, Puerto Rico) for their permission to conduct research on the property and their ongoing support. Professors Paul Wolff, Robert Whitman, Denise O’Malley, Kahlid Abukhidejah, assisted in population monitoring and Margo Attaya assisted in population monitoring and printing and designing materials for Lepidoptera identification guides. Bunker Hill Community College supported, assisted, and funded multiple aspects of this project through an action plan, from The Department of Sustainability, and their Study Abroad Program. Ms. Ileana Soto Rosa (Guaynabo, Puerto Rico), and Ms. Karen Connelly (Brown University, Providence, Rhode Island, USA) assisted in editing. Two reviewers evaluated the paper and made valuable suggestions.

\section{Literature Cited}

Allen, J. 2009. Me and the biospheres: A memoir by the inventor of Biosphere 2. Synergetic Press. Santa Fe, New Mexico, USA. 308 pp.

Bazelet, C. S. and M. J. Samways. 2011. Grasshopper and butterfly local congruency in grasslands remnants. Journal of Insect Conservation 16(1):71-85. http://dx.doi.org/10.1007/s10841-0119394-7

Bergman, K.-O. 2001, Population dynamics and the importance of habitat management for conservation of the butterfly Lopinga achine. Journal of Applied Ecology 38:1303-1313. doi: 10.1046/j.0021-8901.2001.00672.

Ehrlich, P. R., and P. H. Raven. 1964. Butterflies and Plants: A Study in Coevolution. Evolution 18(4):586-608. http://dx.doi.org/10.2307/2406212 
Fleishman, E. and D. D. Murphy. 2002. Minimizing uncertainty in interpreting responses of butterflies to climate change. pp. 55-66. In, Ecological consequences of Climate Change: Mechanisms, Conservation, and Management. E. A. Beever and J. L. Belant (Editors). CRC Press. Taylor \& Francis Group. An Informa business. Boca Raton, Florida, USA. 318 pp.

Hall, S. J. 2011. Tropical and subtropical humid forests. pp. 181-192. In, Pardo, L. H., M. J. Robin-Abbott, and C. T. Driscoll (Editors). Assessment of nitrogen deposition effects and empirical critical loads of nitrogen for ecoregions of the United States. Gen. Tech. Rep. NRS80. Newtown Square, Pennsylvania, USA. U. S. Department of Agriculture, Forest Service, Northern Research Station. 291 pp.

Hughes, J. B., G. C. Daily, and P. R. Ehrlich. 1998. Use of fruit bait traps for monitoring of butterflies (Lepidoptera: Nymphalidae). Revista de Biología Tropical 46(3):697-704.

Karlsson, B. and H. Van Dyck. 2005. Does habitat fragmentation affect temperature-related lifehistory traits? A laboratory test with a woodland butterfly. Proceedings of the Royal Society (London) B. Biological $\quad$ Sciences $\quad$ 272(1569): $1257-1263$. http://dx.doi.org/10.1098/rspb.2005.3074

Lomov, B., Keith, D. A., Britton, D. R. and Hochuli, D. F. 2006. Are butterflies and moths useful indicators for restoration monitoring? A pilot study in Sydney's Cumberland Plain Woodland. Ecological Management \& Restoration 7: 204-210. doi: 10.1111/j.1442-8903.2006.00310.x

Miller, D. G., J. Lane, and R. Senock. 2011. Butterflies as potential bioindicators of primary rainforest and Oil Palm plantation habitats on New Britain, Papua New Guinea. Pacific Conservation Biology 17(2):149-159.

Nelson, M., S. Silverstone, K. C. Reiss, P. Burrowes, R. Joglar, M. Robertson, and T. Vakil. 2010. The impact of hardwood line-planting on tree and amphibian diversity in secondary subtropical wet forest of southeast Puerto Rico. Journal of Sustainable Forestry 29(5):503-516. http://dx.doi.org/10.1080/10549810903479045

Osborn, F., W. Goitia, M. Cabrera, and K. Jaffé. 1999. Ants, plants and butterflies as biodiversity indicators: comparisons between strata in six Neotropical forest sites. Studies of Neotropical Fauna \& Environment 34:59-64.

Pereira Dos Santos, J. 2011. Fruit-feeding butterflies' guide of subtropical Atlantic Forest and Araucaria Moist Forest in State of Rio Grande do Sul, Brazil. Biota Neotropica 11(3). http://dx.doi.org/10.1590/S1676-06032011000300022

Pearson, D. L. and S. S. Carroll. 1998. Global patterns of species richness: spatial models for conservation planning using bioindicator and precipitation data. Conservation Biology 12(4):809-821. http://dx.doi.org/10.1046/j.1523-1739.1998.96460.x

Pérez-Asso, A. R., J. A. Genaro, and O. H. Garrido. 2009. Las mariposas de Puerto Rico. Butterflies of Puerto Rico. Editorial Cocuyo. Carolina, Puerto Rico. 140 pp.

Spitzer, K., J. Jaroš, J. Havelka, and J. Lepš. 1997. Effect of small-scale disturbance on butterfly communities of an Indochinese montane rainforest. Biological Conservation 80:9-15. http://dx.doi.org/10.1016/S0006-3207(96)00079-1

Stefanescu, C., J. Peñuelas, and I. Filella, 2005. Butterflies highlight the conservation value of hay meadows highly threatened by land-use changes in a protected Mediterranean area. Biological Conservation 126:234-246. http://dx.doi.org/10.1016/j.biocon.2005.05.010

Summerville, K. S. 2011. Managing the forest for more than the trees: effects of experimental timber harvest on forest Lepidoptera. Ecological Applications 21:806-816. http://dx.doi.org/10.1890/10-0715.1

Torres, J. A. 1992. Lepidoptera outbreaks in response to successional changes after the passage of Hurrican Hugo in Puerto Rico. Journal of Tropical Ecology 8:285-289. http://dx.doi.org/10.1017/S0266467400006544

Tórrez, N., W. Arendt, and J. M. Maes. 2013. Comunidades de aves y lepidópteros diurnos y las relaciones entre ellas en bosque nuboso y cafetal de Finca Santa Maura, Jinotega. Encuentro [Universidad Centroamericana (UCA), Managua, Nicaragua] 95:69-79.

Vakil, T. 2013. Our Forest. Retrieved from http://eyeontherainforest.org/?page_id=3599

Walker, L. R. 1991. Tree damage and recovery from hurricane Hugo in Luquillo Experimental Forest, Puerto Rico. Biotropica 23(4):379-385. http://dx.doi.org/10.2307/2388255 